\title{
Bone remodeling during alveolar repair is impaired by RANKL antagonist
}

\author{
Remodelação óssea durante o reparo alveolar é prejudicada por antagonista da RANKL \\ La remodelación ósea durante la reparación alveolar se ve afectada por el antagonista de RANKL
}

Received: 01/14/2021 | Reviewed: 01/17/2021 | Accept: 01/18/2021 | Published: 01/24/2021

\author{
Ana Cláudia Ervolino da Silva \\ ORCID: https://orcid.org/0000-0002-6592-0460 \\ Universidade Estadual Paulista "Júlio de Mesquita Filho", Brazil \\ E-mail: anaervolino@hotmail.com \\ Fábio Roberto de Souza Batista \\ ORCID: https://orcid.org/0000-0002-5105-7686 \\ Universidade Estadual Paulista "Júlio de Mesquita Filho", Brazil \\ E-mail.fabiorsbatista@gmail.com \\ Juliana de Moura \\ ORCID: https://orcid.org/0000-0002-2450-5818 \\ Universidade Estadual Paulista "Júlio de Mesquita Filho", Brazil \\ E-mail: Juliana.moura032@outlook.com \\ Juliana Zorzi Coléte \\ ORCID: https://orcid.org/0000-0001-9957-2073 \\ Universidade Estadual Paulista "Júlio de Mesquita Filho", Brazil \\ E-mail: Juliana.zorzi@uenp.edu.br \\ Fernando Chiba \\ ORCID: https://orcid.org/0000-0003-4406-405X \\ Universidade Estadual Paulista "Júlio de Mesquita Filho", Brazil \\ E-mail: fernando.chiba@unesp.br \\ Pedro Henrique Silva Gomes Ferreira \\ ORCID: https://orcid.org/0000-0002-8936-3662 \\ Universidade Estadual Paulista "Júlio de Mesquita Filho", Brazil \\ E-mail: pedroferreirabmf@gmail.com \\ Roberta Okamoto \\ ORCID: https://orcid.org/0000-0002-6773-6966 \\ Universidade Estadual Paulista "Júlio de Mesquita Filho", Brazil \\ E-mail: roberta.okamoto@unesp.br
}

\begin{abstract}
Post-menopausal osteoporosis is detrimental to bone metabolism as well as alveolar repair. This osteometabolic disorder is an obstacle to the success of maxillofacial rehabilitations, since a large number of patients are carriers of the disease. Denosumab is widely used as a treatment for post menopausal osteoporosis. This drug exerts an antiabsorptive action by inhibiting RANKL, helping to reduce the bone loss caused by osteoporosis. This study aimed to evaluate the repair bone formed after the extraction of the upper incisor of estrogen-deficient rats treated with antiRANKL monoclonal antibody. The rats (Rattus novergicus albinus, Wistar) were ovariectomized or SHAM operated $(\mathrm{n}=36)$. Half of the ovariectomized rats were treated with osteoprotegerin with an Fc fragment $(\mathrm{OPG}-\mathrm{Fc} ; 10 \mathrm{mg} / \mathrm{kg}$, twice a week), the other half received saline solution as control. After 30 days the rats had their right upper incisor extracted. After 60 days of extraction, the alveoli were evaluated by immunohistochemical, computerized microtomography and confocal microscopy. The OPG-Fc decreased the percentage of bone volume (BV/TV), thickness (Tb.Th) and number of alveolar trabecules (Tb.N) when compared to groups that received saline solution $(\mathrm{p}<0.005)$. The OPG-Fc increased the separation between the trabecules (Tb.Sp) and the porosity (Po.tot) of the reparative alveolar bone $(\mathrm{p}<0.005)$. The OPG-Fc decreased immunolabelling for RANKL and TRAP when compared to groups that received saline solution. Treatment with OPG-Fc decreased bone neoformation but preserved preexisting bone tissue. This data is supported by the mineral apposition rate, which showed higher values for OVX/OPG-Fc when compared to the OVX group.
\end{abstract}

Keywords: Osteoporosis; Bone remodeling; Bone density; Tooth socket; Denosumab.

\section{Resumo}

A osteoporose pós menopáusica é prejudicial ao metabolismo ósseo, bem como ao reparo alveolar. Essa desordem osteometabólica é um obstáculo para o sucesso das reabilitações maxilofaciais, visto que uma grande parcela dos pacientes são portadores da doença. O Denosumab é amplamente utilizado como tratamento da osteoporose pós menopáusica. Esse medicamento exerce ação antireabsortiva pela inibição do RANKL, auxiliando na diminuição da perda óssea provocada pela osteoporose. Este estudo teve como objetivo a avaliação do osso reparacional formado 
após a exodontia do incisivo superior de ratas com deficiência de estrógeno tratadas com o anticorpo monoclonal antiRANKL. As ratas (Rattus novergicus albinus, Wistar) foram ovariectomizadas ou SHAM operadas ( $n=36)$. Metade das ratas ovariectomizadas receberam tratamento com osteoprotegerina com um fragmento Fc (OPG-Fc; $10 \mathrm{mg} / \mathrm{kg}$, duas vezes por semana), o restante das ratas recebeu solução salina como controle. Após 30 dias as ratas tiveram o incisivo superior direito extraído. Decorridos 60 dias da exodontia, os alvéolos foram avaliados por imunoistoquímica, microtomografia computadorizada e microscopia confocal. A OPG-Fc diminuiu a porcentagem de volume ósseo (BV/TV), espessura (Tb.Th) o número das trabéculas (Tb.N) alveolares quando em comparação aos grupos que receberam solução salina ( $\mathrm{p}<0,005)$. A OPG-Fc aumentou a separação entre as trabéculas $(\mathrm{Tb} . \mathrm{Sp})$ e a porosidade (Po.tot) do osso alveolar reparacional $(p<0,005)$. A OPG-Fc diminuiu a imunomarcação para RANKL e TRAP quando comparada aos grupos que receberam solução salina. O tratamento com OPG-Fc diminuiu a neoformação óssea, mas preservou o tecido ósseo preexistente. Esse dado é suportado pela taxa de aposição mineral, que apresentou valores maiores para OVX/OPG-Fc quando comparado ao grupo OVX.

Palavras-chave: Osteoporose; Remodelação óssea; Densidade óssea; Alvéolo dental; Denosumab.

\begin{abstract}
Resumen
La osteoporosis posmenopáusica es perjudicial para el metabolismo óseo y la reparación alveolar. Este trastorno osteometabólico es un obstáculo para el éxito de las rehabilitaciones maxilofaciales, ya que un gran número de pacientes son portadores de la enfermedad. El denosumab se usa ampliamente como tratamiento para la osteoporosis posmenopáusica. Este fármaco ejerce una acción antiabsorbente al inhibir RANKL, ayudando a reducir la pérdida ósea provocada por la osteoporosis. Este estudio tuvo como objetivo evaluar el hueso de reparación formado tras la extracción del incisivo superior de ratas deficientes en estrógenos tratadas con anticuerpo monoclonal anti-RANKL. Las ratas (Rattus novergicus albinus, Wistar) fueron ovariectomizadas u operadas con SHAM $(\mathrm{n}=36)$. La mitad de las ratas ovariectomizadas fueron tratadas con osteoprotegerina con un fragmento Fc (OPG-Fc; $10 \mathrm{mg} / \mathrm{kg}$, dos veces por semana), la otra mitad recibió solución salina como control. Después de 30 días, se extrajo el incisivo superior derecho de las ratas. Después de 60 días de extracción, los alvéolos fueron evaluados por inmunohistoquímica, microtomografía computarizada y microscopía confocal. La OPG-Fc disminuyó el porcentaje de volumen óseo (BV / $\mathrm{TV}$ ), grosor (Tb.Th) y número de trabéculas alveolares (Tb.N) en comparación con los grupos que recibieron solución salina ( $\mathrm{p}<0,005$ ). La OPG-Fc aumentó la separación entre las trabéculas (Tb.Sp) y la porosidad (Po.tot) del hueso alveolar reparador ( $\mathrm{p}<0,005)$. El OPG-Fc disminuyó el inmunomarcaje de RANKL y TRAP en comparación con los grupos que recibieron solución salina. El tratamiento con OPG-Fc disminuyó la neoformación ósea pero conservó el tejido óseo preexistente. Estos datos están respaldados por la tasa de aposición de minerales, que mostró valores más altos para OVX / OPG-Fc en comparación con el grupo OVX.
\end{abstract}

Palabras clave: Osteoporosis; Remodelación ósea; Densidad osea; Alvéolo dental; Denosumab.

\title{
1. Introduction
}

Osteoporosis is a worldwide public health problem, and its incidence is rising, in view of the increased life expectancy of the population. Thus, osteoporosis is a disease of great importance, since it makes the individual carrier more susceptible to bone fractures that can lead to death (Eastell, 1998). This osteometabolic disorder occurs when there is an imbalance in bone remodeling, with an overlap of the rate of bone resorption over the rate of bone formation. After menopause, estrogen deficiency increases osteoclastic activity without a corresponding increase in osteoblastic activity, leading to osteopenia, which affects about two thirds of the female population. When it is associated with age, estrogen deficiency causes osteoporoses (Gallagher, 2008).

Denosumab is a fully human monoclonal antibody that acts by inhibiting RANKL, one of the main modulators of osteoclastogenesis, being the first RANKL molecule inhibitor approved by the FDA for use in postmenopausal women at risk of osteoporosis. In humans it is administered subcutaneously in doses of 60mg every six months. Antibodies against RANKL are powerful antiabsorbing agents (Kostenuik et al., 2009; Adami et al., 2012), however they do not interact with murine RANKL. Osteoprotegerin (OPG) is a natural RANKL antagonist. When an Fc fragment (OPG-Fc) is added to the OPG, its survival in the bloodstream is extended. Mouse OPG-Fc can be used to study the effects of anti-RANKL treatment on mouse models (Kostenuik et al., 2009; Ominsky et al., 2008).

Ovariectomy of rats has been associated with increases in RANKL protein (Kostenuik et al., 2009; Nakamichi et al., 
2007), demonstrating that RANKL is responsible, in parts, for the bone loss that occurs when there is estrogen depletion in mice. To support this, studies have shown that RANKL inibition by OPG decreased bone resorption in animals with estrogen deficiency (Yoneda et al., 2004; Kostenuik et al., 2001). The evaluation of the bone architecture in face of the anti-RANKL action in ovariectomized rats has been poorly studied until the present moment, making this model interesting, since it mimics a condition that is present in a large part of the population.

The evaluation of alveolar repair after extraction of the rat upper incisor is a classic model used to study the dynamics of bone repair (Okamoto \& Russo., 1973; Manrique et al., 2015), since the chronology of the process as well as the cellular responses are very well defined. It is an interesting model when the purpose is to characterize the alveolar bone, since the objective is the production of tissue with adequate quality for rehabilitation with implant-supported prosthesis.

Considering the prevalence of osteoporosis cases, as well as the increased demand for procedures to replace lost teeth, the objective of this study was to evaluate the alveolar repair process in rats with estrogen deficiency and treated with OPG-Fc, through immunohistochemical analysis, microtomographic analysis and confocal microscopy analysis.

\section{Material and Methods}

\subsection{Study design and ethics committee}

This research was approved by the Ethics Committee on Animal Use of Araçatuba Dental School, UNESP - Paulista State University (process 00685-2015). The whole study was developed according to the ARRIVE guidelines. A total of 36 rats (Rattus novergicus albinu, Wistar), three months old, whose body weight ranged from 250 to 300 grams, were used. The animals were kept in cages in a stable temperature environment $\left(22^{\circ} \mathrm{C} \pm 2^{\circ} \mathrm{C}\right.$ light control cycle 12 hours light and 12 hours dark), balanced diet (Ração Mogiana Alimentos SA, Campinas, Brazil) and water ad libitum, except in the period of 12 hours preceding the surgical act. The animals were divided into 3 groups: SHAM (n=12), OVX (n=12) e OVX/OPG-Fc (n=12) (Table 1). The animals underwent ovariectomy or sham surgery. The SHAM and OVX animals were treated with saline vehicle, while the OVX/OPG-Fc animals were treated with OPG-Fc by subcutaneous route. The treatments started right after the surgery and lasted until the end of the experiment, totaling 90 days of administration. 30 days after the ovariectomy, the right upper incisor was extracted and after 60 days the samples were collected for analysis. Six jaws were destined for immunohistochemical analysis using the Osteoprotegerin (OPG), nuclear factor activator receptor binder kappa B (RANKL), Osteocalcin (OCN) and Acid Tartarate Resistant Phosphatase (TRAP).For the evaluation of the reparative bone tissue using computerized microtomography, the evaluation parameters were selected based on guidelines described previously (Bouxsein et al., 2019). The parameters evaluated were bone volume (BV/TV), trabecular thickness (Tb.Th), trabecular separation (Tb.Sp), number of trabeculars (Tb.N) and total porosity [Po. (tot)]. The microtomographic analysis was performed using 6 jaws from each experimental group. After computerized microtomography, the same maxilla (n=6) were processed for confocal microscopy analysis for the histometrical evaluation of bone dynamics and mineral apposition rate (MAR).

Table 1. Experimental groups according to the experimental surgeries and treatment.

\begin{tabular}{lc}
\hline SHAM & Sham surgery \\
OVX & Ovariectomy \\
OVX/OPG-Fc & Ovariectomy and anti-RANKL treatment \\
\hline
\end{tabular}




\subsection{Estral cycle classification}

The rats were separated in individual cages for daily evaluation of the estral cycle. The technique used was described by Evans and Long in 1922 (Evans \& Long., 1922), which consists of introducing 1-2 drops of saline solution inside the vagina followed by aspiration. The collected serum is placed on a histological slide for visualization under the microscope to recognize the phases of the estral cycle. The rats are selected after following 3 regular cycles.

\subsection{Ovariectomy surgery}

The estrogen deficiency was induced by removing the ovaries from the mice (Teófilo et al., 2004). The rats of the OVX and OVX/OPG-Fc groups were anesthetized by intramuscular injection with 50mg/kg Ketamine and 5mg/kg Xylazine (Dopaser - Laboratório Calier do Brasil Ltda - Osasco, São Paulo, Brazil), then antisepsis of the surgical field was performed with iodinated polyvinylpyrrolidone (Riodeine Indústria Química e Farmacêutica Rio Química, Ltda). The incisions were made in the region of both flanks, to expose the ovaries and remove them. After the hemostasis, the skin was sutured with cotton thread. As prophylaxis, 0.02 of antibiotic (Pentabiótico® Veterinário Pequeno Porte, Fort Dodge Animal Health Ltda., Campinas, SP, Brazil) was administered to the animals after the surgery. The SHAM rats were submitted to sham surgery, in which only surgical access to the ovaries is performed, without their removal, in order to submit the rats to the same surgical stress, as the ovariectomized ones.

\subsection{Drug Treatment}

The drug treatment with OPG-Fc was administered subcutaneously at a dose of $10 \mathrm{mg} / \mathrm{kg}$, twice a week corroborating the experimental model described in previous studies (Gerstenfeld et al., 2009). The treatment lasted until the end of the experiment (euthanasia), totaling 90 days of administration. During the same period, SHAM and OVX animals were treated with saline solution subcutaneously.

\subsection{ELISA}

After 30 days of OPG-Fc administration, blood samples were collected and stored in tubes before being centrifuged to separate the blood plasma. The level of nuclear activator receptor binder kappa B (RANKL) was determined by an Enzyme Linked ImmunonoSorbent Assay (Booster Biological Technology Co., Ltda., Pleasanton, CA, USA), to verify the efficacy of the OPG-Fc dose used (Figure 1). 
Figure 1. Absorbance of RANKL expressed in SHAM groups (45 pg/ml) OVX (91 pg/ml) and OVX/OPG-Fc (41 pg/ml) obtained by ELISA. Evaluation period: 30 days after starting anti-RANKL treatment.

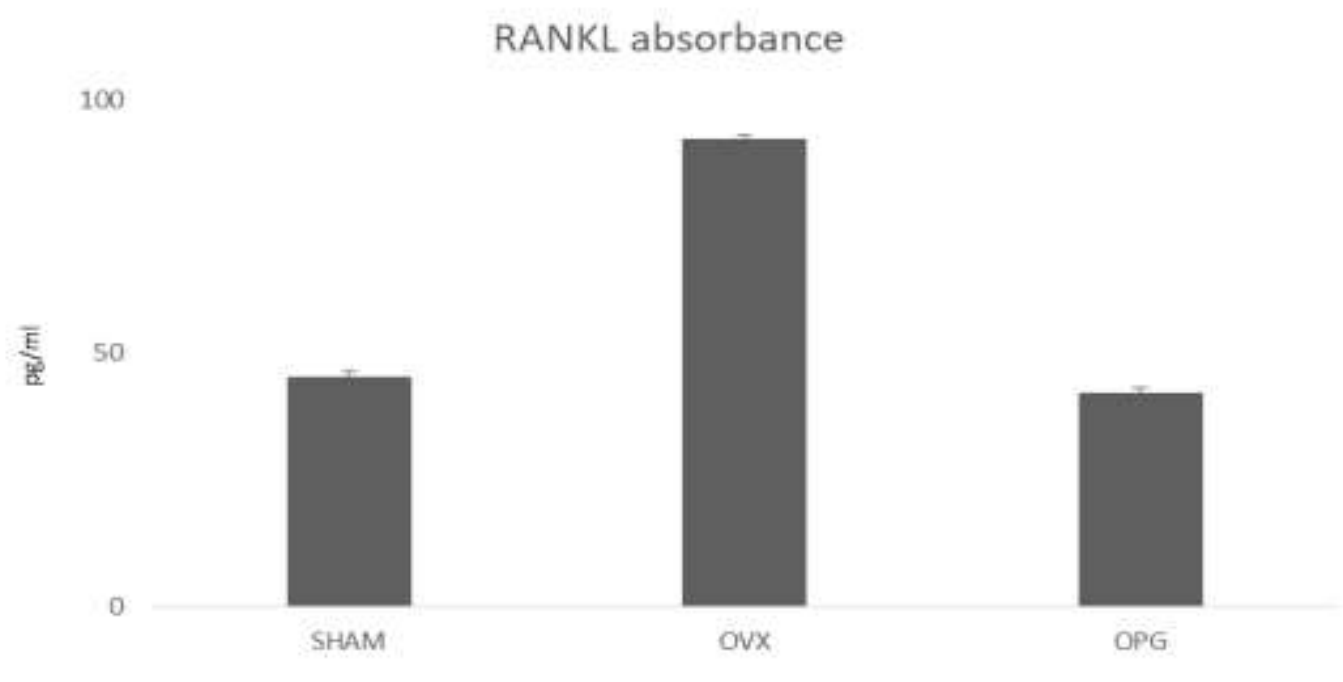

Source: Authors.

\subsection{Exodontic Surgery}

After 30 days of starting the drug treatment, the 36 rats were submitted to extraction of the right upper incisor. The animals were submitted to fasting for eight hours before the surgery. They were sedated with a combination of $50 \mathrm{mg} / \mathrm{kg}$ of intramuscular ketamine (Vetaset ${ }^{\circledR}$ - Fort Dodge Animal Health Ltda., Campinas, SP, Brazil) and $5 \mathrm{mg} / \mathrm{kg}$ of xylazine hydrochloride (Dopaser - Laboratórios Calier do Brasil Ltda., Osasco, SP, Brazil). Then the antisepsis of the operative field was performed using topical iodopovidone germicide (10\% PVP-I, Soft Derma Degerming Riodein, Rioquímica, São José do Rio Preto, SP, Brazil) and the upper right incisor was extracted using a specially adapted instrument. The gingival mucosa was sutured with 910 polyglactin yarn (Vicryl 4.0).

\subsection{Fluorochrome application.}

The application of fluorochromes was performed on 6 animals of each group (SHAM,OVX and OVX/OPG-Fc). Thus, at 14 days after extraction of the right upper incisor it was administered by the intramuscular route $20 \mathrm{mg} / \mathrm{kg}$ of fluorocromo calcein. After 28 days (42 days after extraction), the alizarin red fluorochrome was administered intramuscularly in the amount of $20 \mathrm{mg} / \mathrm{kg}$ (Oliveira et al., 2019).

\subsection{Euthanasia}

All animals were euthanized 60 days after the exodontic surgery $(n=18$ : immunohistochemical analysis; $n=18$ : fluorochrome analysis and computerized microtomography) with a lethal dose of intravenous anesthetic (sodium thiopental, $150 \mathrm{mg} / \mathrm{kg}$ ) (Cristália Ltda., Itapira, SP, Brazil).

\subsection{Immunohistochemical Analysis}

For this analysis, the right side of the jaw was removed and fixed in $10 \%$ formaldehyde. After 48 hours, the samples were washed in running water for 24 hours and decalcified in EDTA (10\%). Then dehydration was performed using a sequence of alcohols. The diaphanization was performed with xylol for later inclusion in paraffin, to obtain cuts with $5 \mu \mathrm{m}$ of thickness and later mounted on histological slides. The immunohistochemical reactions were performed in order to analyze the 
bone remodeling response using RANKL and OPG proteins. The presence of TRAP, positive in osteoclasts, indicates bone resorption. Osteocalcin (OC) is deposited on the bone matrix during the bone mineralization process, when this tissue is mature. These proteins were analyzed in a period of 60 days after the exodontic surgery.

Immunohistochemical reactions were performed using the immunoperoxidase detection method. The secondary antigoat IgG rabbit antibody $(\mathrm{H}+\mathrm{L})$, Biotin (Pierce Biotechnology, Waltham, Massachusetts, USA) was used; the signal of the reaction was amplified through incubation in avidin and biotin (Kit ABC standard, Vector Laboratories); the reaction was revealed using the chromogen Diaminobenzidine (Dako North America, Inc. 6392 Via Real Carpinteria, CA 93013, USA). At the end of the immunohistochemical reactions, counter-coloration with Harris Hematoxylin was performed. For each of the antibodies used, the expression of these proteins was evaluated by ordinal qualitative analysis through the attribution of different scores according to the extension of the area of positive immunomark for diaminobenzidine during the alveolar repair process. The analysis was performed with an optical microscope (Leica, Leitz Wetzlar, Germany, 25x objective). For 25\% of positive immunolabeling, it will be attributed the score 1 ; for $50 \%$ score 2 ; and for $75 \%$ score 3 . The analyzer was submitted to the Kappa test where the index above 0.8 was obtained, showing that the observed scores were consistent. Diaminobenzidine markings were considered positive, being cautious to maintain negative controls for antibody specificity evaluation. These scores were established based on previous studies (Pedrosa et al., 2009; Ramalho-Ferreira et al., 2017).

\subsection{Computerized Microtomography}

For the three-dimensional analysis, the jaws were removed, fixed in $10 \%$ formaldehyde and stored in $70 \%$ alcohol. The pieces were examined for the first time by scanning X-ray beams in a digital computerized microtomography system. The parts were scanned by the SkyScan microtomograph (SkyScan 1272 Bruker MicroCT, Aatselaar, Belgium, 2003) using cuts of $9 \mu \mathrm{m}$ thickness $(50 \mathrm{Kv}$ and $500 \mu)$, with copper and aluminum filter and rotation pitch of $0.3 \mathrm{~mm}$. The images obtained by X-ray projection on the samples were stored and reconstituted after the determination of the region of interest (ROI), using NRecon software (SkyScan 2011, version 1.6.6.0, Bruker, Aartselaar, Belgium). In the DataViewer software (SkyScan, version 1.4.4 64-bit, Bruker, Aartselaar, Belgium), the images were reconstructed to adjust the standard positioning of all samples, and observed in three planes (transverse, longitudinal and sagittal). Then, using the software CTAnalyser - AWC (SkyScan Bruker MicroCT version 1.12.4.0, Bruker, Aartselaar, Belgium), the area of interest (ROI) for the three-dimensional evaluation was defined. The middle third of the alveolar cavities was scanned in the apical to cervical direction in the longitudinal plane. The CTAnalyser software was then used to analyze and measure the image according to the gray scale (threshold). The threshold had from 25 to 90 shades of gray, which made it possible to obtain the volume of bone formed in the alveoli under repair.

The parameters used for the evaluation were percentage of bone volume (BV/TV), number of trabecules (Tb.N), separation between the trabecules (Tb.Sp), thickness of trabecules (Tb.Th) and total porosity [Po (tot)].

\subsection{Confocal Laser Microscopy}

After obtaining the results from Micro-CT, the samples were washed in running water for 24 hours and dehydrated with gradually increasing concentrations of alcohol. Then, the jaws were infiltrated in a solution of acetone and methyl methacrylate MMAL (Classic, Classic Dental Articles, São Paulo, SP, Brazil) in a proportion of 1:1, followed by baths of methyl methacrylate. The $1 \%$ benzoyl peroxide catalyst (Riedel - De Haën AG, Seelze - Hannover, Germany) was added to the last bath. The pieces were placed in glass flasks with caps which were kept at a temperature of $37^{\circ} \mathrm{C}$ for 5 days until the resin was polymerized. After polymerization, the blocks containing the specimens were initially reduced with a "Maxcut" drill mounted on a Kota bench motor (Strong 210, São Paulo, SP, Brazil), parallel to the long axis of the hemimaxilla (sagittal plane). Then, the progressive manual wear was performed in automatic polishing (ECOMET 250PRO/AUTOMET 250, 
Buehler, Lake Bluff, IL, USA) with 120, 300, 400, 600, 800 and 1200 grain sandpapers (Carbimet 2, Buehler, Lake Bluff, IL, USA), under fluorescent light, up to the thickness of $80 \mu \mathrm{m}$ measured by digital pachymeter (Mitutoyo, Pompeia, SP, Brazil). The cuts obtained were mounted on histological blades with mineral oil (Petrolato líquido, Mantecor, Taquara, RJ, Brazil) and fixed with laminules and enamel to prevent the oil from emptying, preventing the cut from drying out. The longitudinal sections of the alveolar bone of the hemimaxillas adjacent to the apical third of the upper central incisor were obtained by the Leica CTR 4000 CS SPE microscope (Leica Microsystems, Heidelberg, Germany), using a 10x objective (original magnification 100). The bone next to the right upper incisor was taken as reference. Thus, the area of bone around this tooth was evaluated in each sample. After selecting the thickness of the sections, the images were reconstructed in the software used to manipulate the microscope (Leica CTR 4000 CS SPE, Leica Microsystems, Heidelberg, Germany). The images obtained showed through the blue filter, the green color fluorochrome. The alizarin fluorochrome was revealed in red by the green filter. Overlaying the images of the two fluorochromes it was possible to evaluate the calcium deposition in both periods. The images were saved in TIFF format and moved to ImageJ software (Image Processing and Analysis Software, Ontario, ON, Canada). Using the "color selection" tool, each image was standardized according to hue, saturation and brightness. Both fluorochrome stains were evaluated in the same configuration on the same slide for bone dynamics and mineral apposition rate (MAR) values. The green fluorescent color (calcein) was selected, and the measurement tool was used to calculate the corresponding area in square micrometers. Then, the fluorescent red (alizarin) was measured, thus making possible the interpretation of periimplant bone dynamics in each tested condition. The rate of mineralization was obtained by the daily value of the mineralization, using a straight tool to calculate the distance between the external surfaces of each fluorochrome precipitation (beginning of the calcein precipitation until the end of the alizarin precipitation). These values were divided by 28 to represent the interval days between the two fluorochrome injections. The result represented the value of the mineral apposition per day (MAR) in micrometers.

\subsection{Statistical Analysis}

Statistical analysis, performed for micro-CT analysis (BV/TV BV, Tb.Th, Tb.N, Tb.Sp and Po.Tot) and confocal microscopy (Bone dynamic and MAR), was performed using the GraphPad Prism 7.01 software. Homogeneity and homoscedasticity tests (Shapiro-Wilk) were performed to select the appropriate statistical data. After confirmation of the normal distribution, the one-way Anova test was performed to compare the results obtained in the SHAM, OVX and OVX/OPG-Fc group followed by Tukey's post-test when necessary. For all statistical analyses a 95\% significance level $(\mathrm{p}<0.05)$ was adopted.

\section{Results}

\subsection{Immunohistochemical Analysis}

The immunohistochemical reaction was done to characterize the stage of bone tissue development in the different experimental groups through the expression of osteocalcin (extracellular matrix protein expressed in later periods, when calcium is precipitated in the bone tissue), as well as the balance of the bone remodeling process through the expression of RANKL, OPG (proteins related to bone resorption and formation, respectively) and TRAP, related to osteoclastic activity and bone resorption. The objective of the immunolabeling was to evaluate the efficacy of the drug in neutralizing the RANKL protein, and the responses of the bone tissue under repair to the OPG-Fc action. The markings are evaluated in the middle third of the alveolus under repair, region of greater cellular activity. It is possible to observe the expression of the proteins in the cells by means of the brownish coloration, which is given by the use of the chromogen diaminobenzidine (Figure 2A-L). The immunohistochemical analysis is qualitative ordinal, in which the attribution of scores is made according to the extension of 
the area that presents immunocoloration (Table 2). Osteoprotegerin was positively marked in the three experimental groups. In SHAM animals, light to moderate markings were observed in osteoblasts present in mature bone tissue (Figure 2A). In the OVX group, moderate immunomarking of osteoblasts, present in the conjunctive tissue, was observed (Figure 2B). Although moderate immunolabeling was observed in this exeperimental group, it is important to emphasize that the immunolabeling was close to the non-mineralized tissue, showing the delay in the alveolar bone repair response. When the group treated with OPGFc was analyzed, moderate immunolabeling of active osteoblasts in the bone tissue formed in the middle third of the alveolus was observed, showing better bone repair in view of the OVX group (Figure 2C). Moderate marking for RANKL was observed in the SHAM group (Figure 2D), showing balance in the bone remodeling process, since the OPG also presented itself in a moderate manner. In OVX animals intense immunolabeling for RANKL was observed, highlighting that in this group little bone tissue was observed in the middle third of the dental alveolus, with a predominance of connective tissue in this region (Figure 2E). In the group treated with OPG-Fc, light immunomarkings for RANKL were observed in the bone tissue (Figure 2F). Osteocalcin was marked in osteoblasts in the final stage of mineralization, characterizing a more mature bone tissue. In the SHAM group, the OCN was marked mainly in osteocytes present in the alveolar bone tissue, with moderate marking (Figure 2G). The presence of osteocytes positively marked for osteocalcin characterizes the degree of maturity of the bone formed in the alveolar bone. In the OVX group, moderate marking was observed in osteoblasts in connective tissue, without presenting mineralization characteristics (Figure 2H). In the OVX/OPG-Fc group, bone tissue formed in the alveolus was observed, with moderate marking for osteocalcin (Figure 2I). TRAP was marked in mature osteoclasts in bone resorption activity. In SHAM animals a discrete positive mark was observed for osteoclasts, indicating low osteoclastic activity (Figure 2J). In the OVX group, moderate to intense marking was observed in mature osteoclasts and greater presence of connective tissue (Figure 2K). In the animals of the group treated with OPG-Fc, light marking was observed in active osteoclasts with presence of connective tissue (Figure 2L).

Figure 2. Immunohistochemistry using proteins against OPG, RANKL, OCN and TRAP in the period of 60 days. Immunolabelling of these proteins in SHAM, OVX, and OVX/OPG-Fc groups. (Original, 25×). Immunolabelling was defined as: mild; moderate and intense. The yellow arrows show the immunolabelling of proteins in the extracellular matrix.

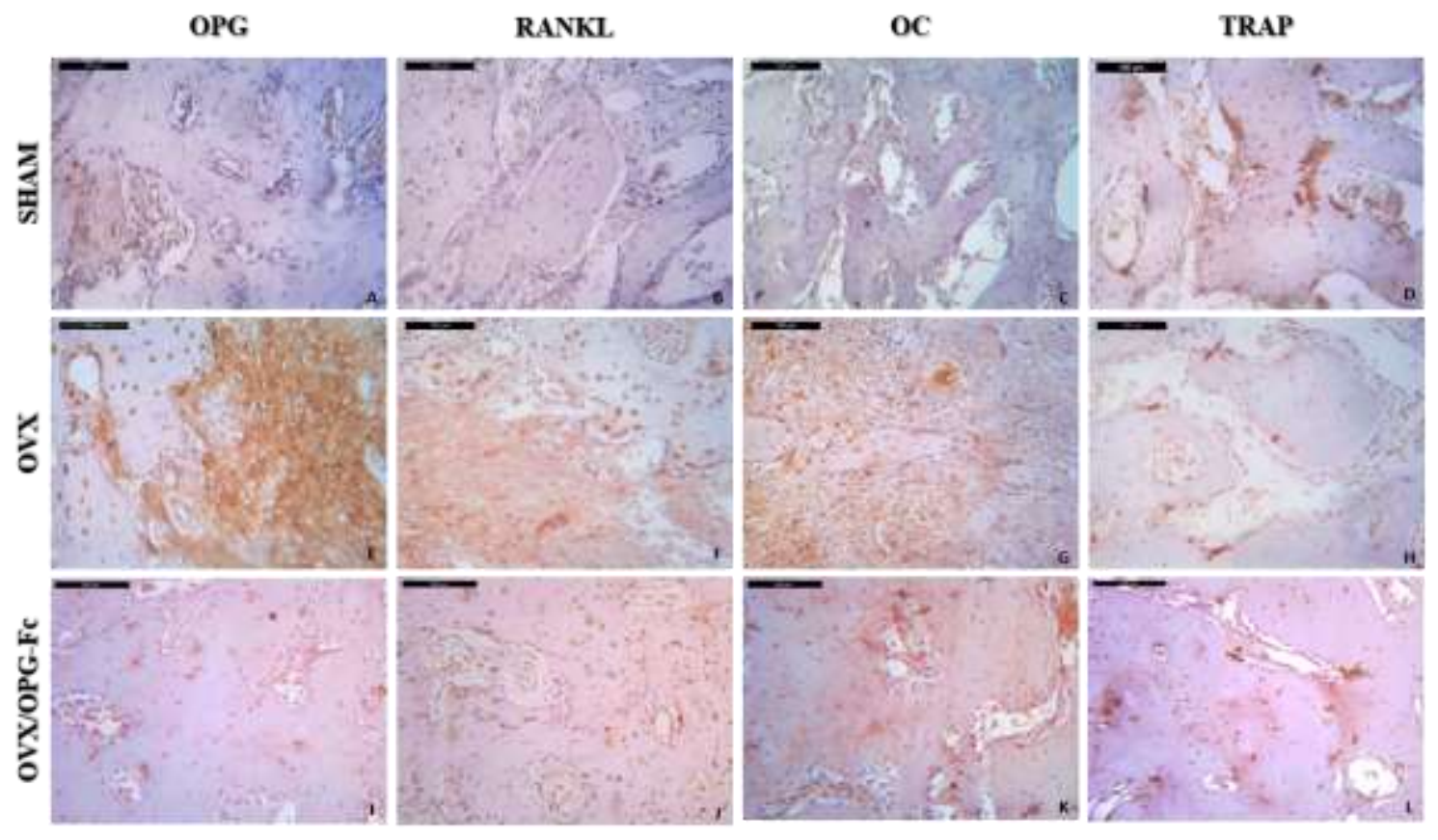

Source: Authors. 
Table 2. Immunolabelling scores for the OPG, RANKL, OCN and TRAP proteins at the different experimental groups.

\begin{tabular}{clllll}
\hline & OPG & RANKL & OCN & TRAP \\
\hline & SHAM & 2 & 2 & 2 & 1 \\
& OVX & 2 & 3 & 2 & 3 \\
PG-Fc & OVX/O & 2 & 1 & 2 & 1 \\
\hline
\end{tabular}

Source: Authors.

\subsection{Computerized Microtomography}

The SHAM group presented the best results for percentage of bone volume $(45.31 \%)$, with statistically significant difference when compared to other groups $(\mathrm{p}<0.05)$. For this same parameter, OVX and OVX/OPG-Fc values were $31.57 \%$ and $23.05 \%$, respectively, with statistically significant difference. As for the trabecular thickness, SHAM presented the highest values $(0.09223 \mathrm{~mm})$, followed by the OVX group $(0.07422 \mathrm{~mm})$ and OVX/OPG-Fc, with the lowest value $(0.07289 \mathrm{~mm})$. Statistical differences were between the SHAM/OVX $(\mathrm{p}<0.005)$ and SHAM/OVX/OPG-Fc $(\mathrm{p}<0.005)$ groups. Bone trabecules from the SHAM group were less separated in relation to the other groups $(0.1802 \mathrm{~mm})$, followed by the OVX group (0.2246 $\mathrm{mm})$ and the highest values were observed in the OVX/OPG-Fc group $(0.3493 \mathrm{~mm})$, which showed greater separation of trabecules. Statistically significant difference was observed between the SHAM and OPG-Fc groups (p<0.05). The animals of the SHAM group presented the highest number of bone trabecules $(4.933 / \mathrm{mm})$, followed by the OVX $(4.324 / \mathrm{mm})$ and OVX/OPG-Fc $(3.161 / \mathrm{mm})$ groups, where the lowest number of trabecules was observed, with statistically significant difference only between the SHAM and OVX/OPG-Fc groups $(\mathrm{p}<0.05)$. Higher porosity was observed in the OVX/OPG-Fc group $\left(76 \mathrm{~mm}^{2}\right)$, followed by the OVX group $\left(68.43 \mathrm{~mm}^{2}\right)$ and with lower porosity the SHAM group (54.69 $\left.\mathrm{mm}^{2}\right)$. All groups presented statistical difference when compared $(\mathrm{p}<0.05)$ (Figure 3A-E). 
Figure 3. Parameters obtained by computerized microtomography: Percentage of bone volume (A); Trabecular thickness (B); Trabecular separation (C); Number of trabecules (D); Total porosity (E). The long axis of the alveolus has been defined as ROI. The statistical difference between the groups is represented by different letters in the graph . (p > 0.05, one-way ANOVA).
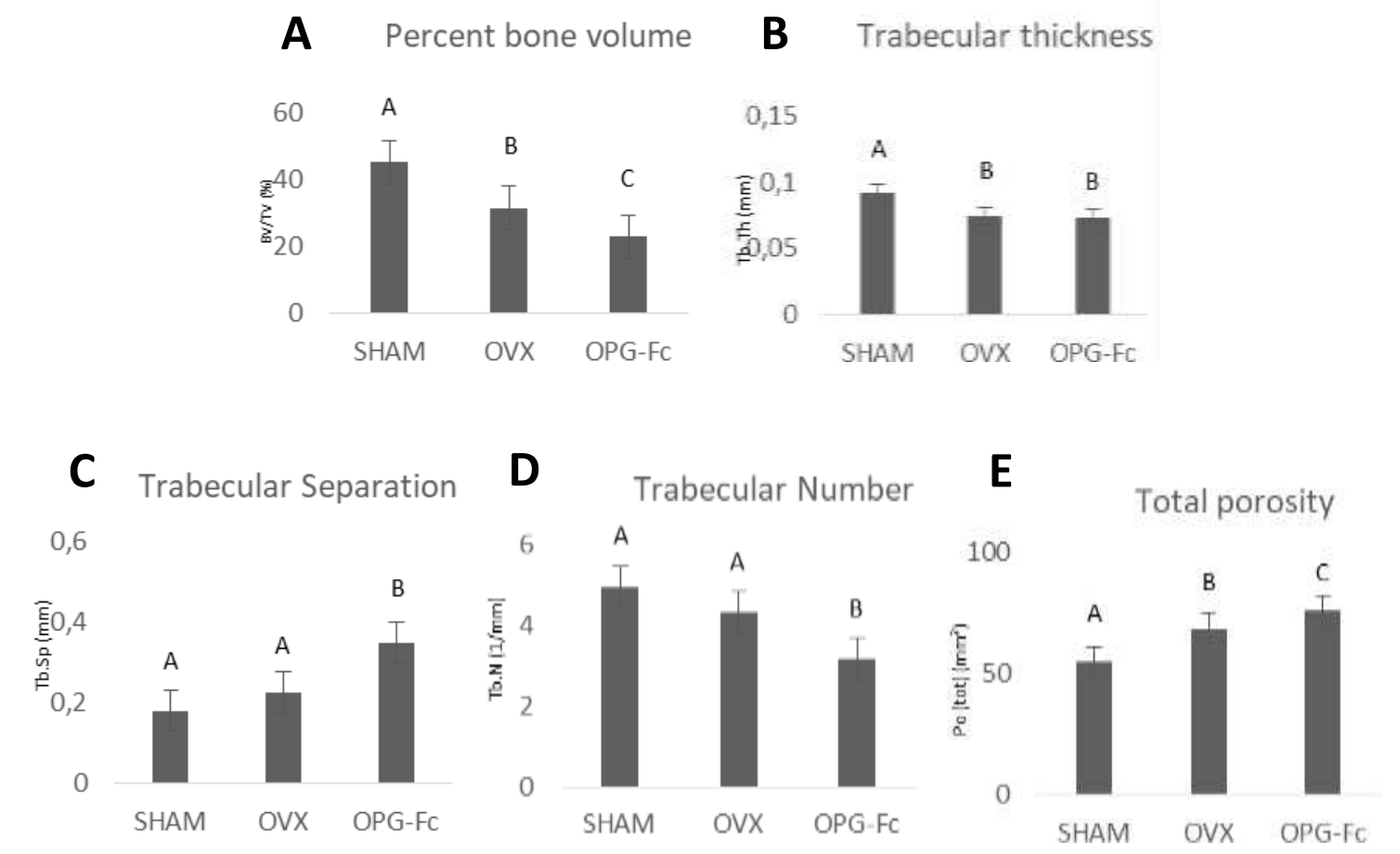

Source: Authors.

\subsection{Confocal Laser Microscopy}

Fluorochromes have the property to bind to calcium at the time of matrix precipitation. Therefore, the extent of fluorochrome marking represents the amount of calcium precipitation, thus allowing the measurement of the bone formation event. Another aspect to consider is the period in which the fluorochromes were injected; as the first was calcein (green), the bone marked (calcium precipitation) with the green fluorochrome represents the old bone. The last fluorochrome injected was alizarin; therefore, the marked bone (calcium precipitation) with red fluorochrome represents the most recent bone. Considering these points, it can be said that the different colors represent the different periods of bone formation (Figure 4). The SHAM group presented the best bone renewal rate according to the alizarin precipitation. The OVX and OVX/OPG-Fc groups showed a delay in bone neoformation, but the OVX/OPG-Fc group showed a high precipitation of calcein, indicating a large amount of old bone and proving the effectiveness of the drug in inhibiting bone resorption.

In the results obtained by the histometric analysis (Bone dynamics), the SHAM group showed the largest area of alizarin, corresponding to bone neoformation $\left(47409,85675 \mu \mathrm{m}^{2}\right)$, while the OVX/OPG-Fc group showed a larger area of fluorochrome calcein $\left(94863,1205 \mu \mathrm{m}^{2}\right)$, indicating a lower rate of resorption. There was no statistical difference between the groups (Figure 5). As for the mineral apposition rate the SHAM group presented a higher value $(2 \mu \mathrm{m})$. The OVX/OPG-Fc group had similar values to the SHAM group $(1.865714 \mu \mathrm{m})$, while the OVX group had lower mineral apposition rate $(1.310286 \mu \mathrm{m})$. There was a statistically significant difference between SHAM/OVX (p<0.0001) and OVX/OPG-Fc $(\mathrm{p}<0.0001)$ (Figure 6). 
Figure 4. Calcein (green) and alizarin (red) marking of the fluorescent lines in the calcium matrix, demonstrating the dynamics of the alveolar bone of the experimental groups: SHAM, OVX e OVX/OPG-Fc.
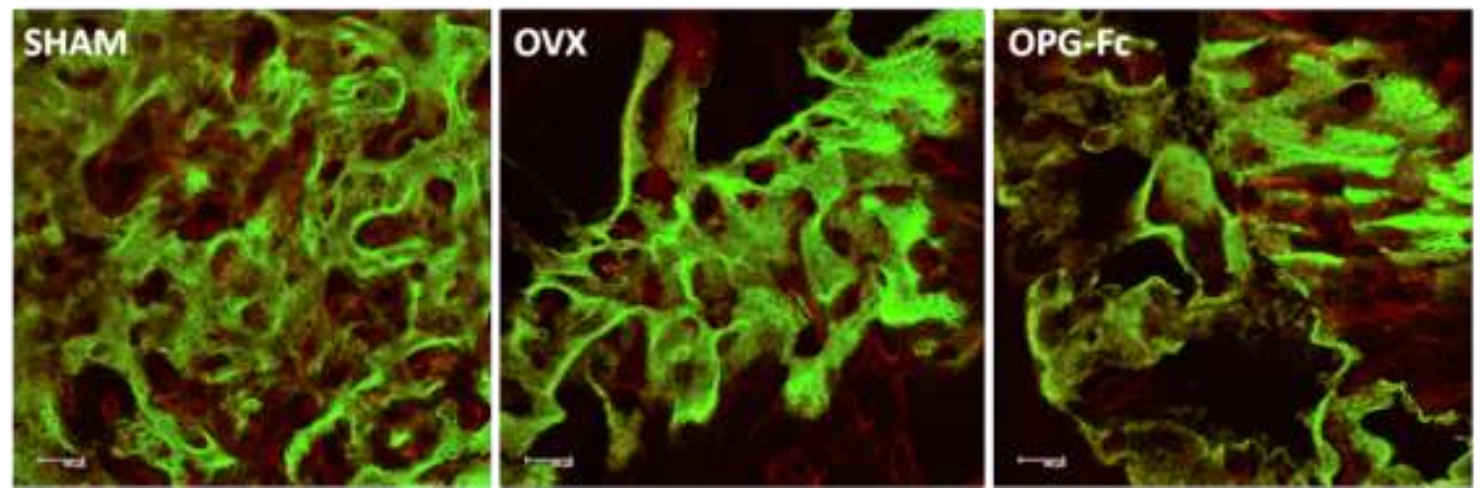

Source: Authors.

Figure 5. Evaluation of bone dynamics represented by precipitation of calcein (old bone) and alizarin (new bone) in the alveoli under repair. SHAM: calcein: 78599,265 $\mu \mathrm{m}^{2}$, alizarin: 47409,85675 $\mu \mathrm{m}^{2}$; OVX: calcein: 53481,456 $\mu \mathrm{m}^{2}$, alizarin: 37582,0175 $\mu \mathrm{m}^{2}$; OVX/OPG-Fc: calcein: 94863,1205 $\mu \mathrm{m}^{2}$, alizarin: 31111,9605 $\mu \mathrm{m}^{2}$. There was no statistical difference between the groups.

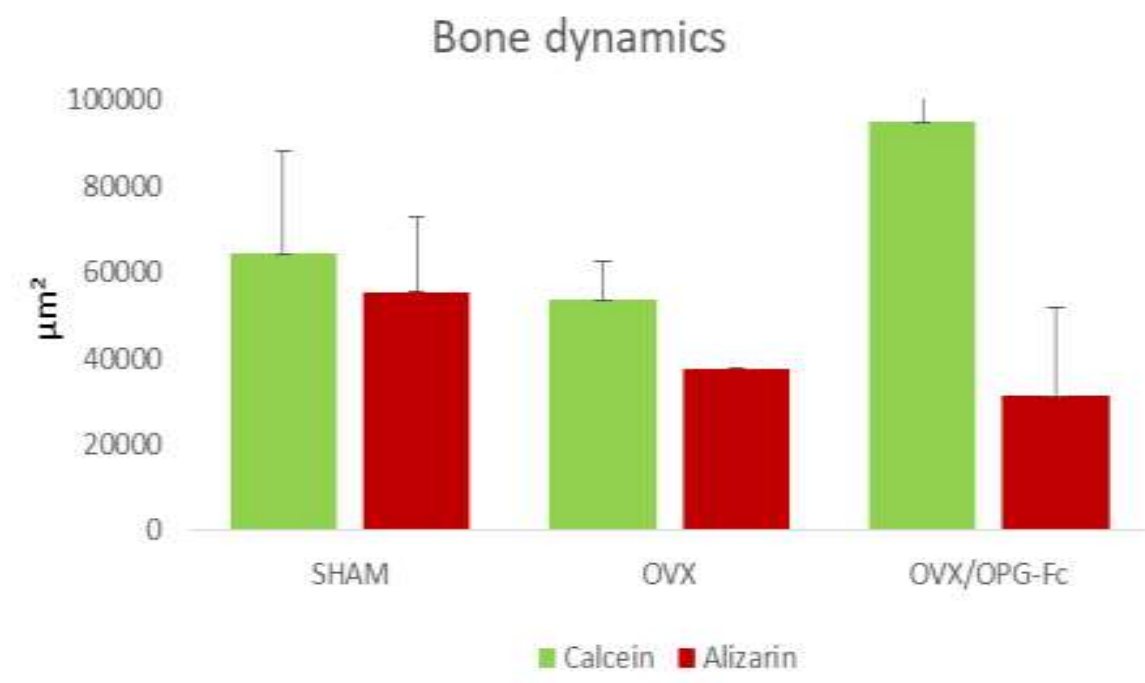

Source: Authors. 
Figure 6. Evaluation of the mineral apposition rate per day ( $\mu \mathrm{m})$. SHAM: $2 \mu \mathrm{m}$; OVX: 1,310286 $\mu \mathrm{m}$; OVX/OPG-Fc: 1,865714 $\mu \mathrm{m}$. The statistical difference between the groups is represented by different letters in the graph $([-\mathrm{p}<0.05$, Tukey).

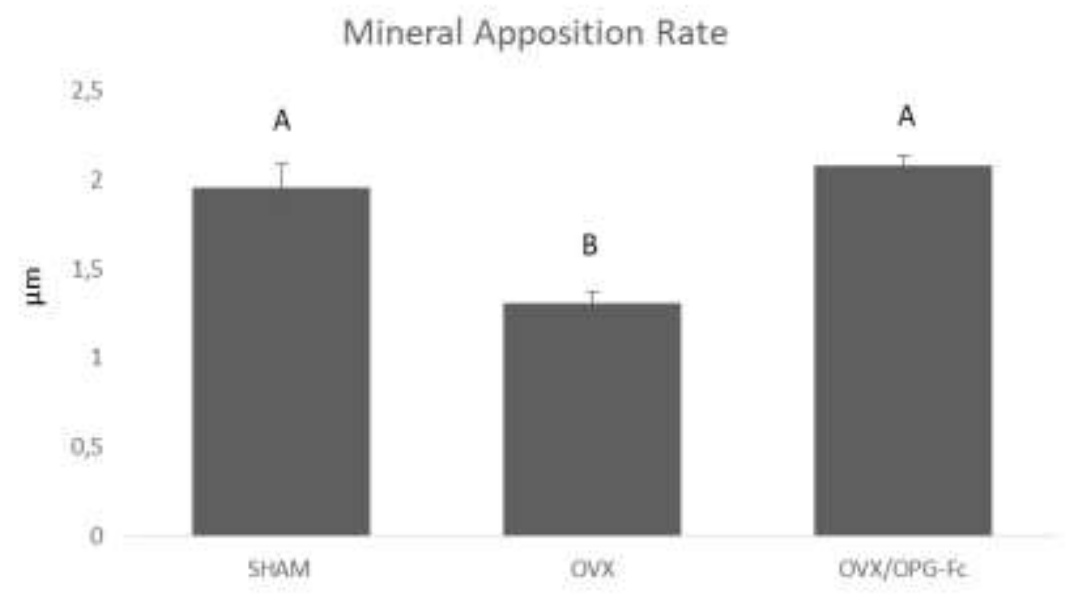

Source: Authors.

\section{Discussion}

The treatment with OPG-Fc was not able to promote improvement of the microarchitecture of the reparative bone tissue in rats with estrogen deficiency, however the results of confocal microscopy showed great preservation of the old bone, evidenced by the calcein, resulting from the antiabsortive action of OPG-Fc. Corroborating with these results, the marking of the proteins by immunohistochemical allows us to affirm that the drug treatment was able to exercise its anti-RANKL function, since the group treated with OPG-Fc presented the lightest markings for this protein that is closely associated with bone resorption.

The experimental model of alveolar repair is useful to study the dynamics of bone tissue, since this process has its chronology well defined (Okamoto \& Russo., 1973). The experimental model of ovariectomy in rats is useful for inducing estrogen deficiency and analyzing its impacts on bone tissue (Teófilo et al., 2004). The data obtained by the ELISA test proved the increase in serum RANKL levels in the OVX group, caused by estrogen deficiency, as well as the efficacy of the medication dose administered in the OVX/OPG-Fc group. The monoclonal antibody OPG-Fc can be used to study the action of denosumab in murinos. The dose of OPG-Fc was selected based on a previous study that proved the efficacy of the drug in rats (Ominsky et al., 2008; Gerstenfeld et al., 2009).

The SHAM group, considered as a positive control, presented the best bone formation responses by the proposed analyses. The bone tissue was repaired as expected (Okamoto \& Russo., 1973). Ovariectomy triggered harmful cellular responses during alveolar repair, which are represented by the larger immunohistochemical marking area for RANKL, and smaller for OPG, suggesting an imbalance in the remodeling process, with predominance of bone resorption, caused by estrogen deficiency. This result is corroborated by the intense expression of TRAP, related to the activity of osteoclasts. It is worth mentioning that a greater presence of connective tissue was observed in the OVX group, characterizing a delay in the alveolar repair process. These findings are in accordance with the results obtained by (Luvizuto et al., 2009; Ramalho-Ferreira et al., 2017), who observed that ovariectomy leads to the loss of bone formation responses, leading to a delay in alveolar repair. Furthermore, the parameters obtained by computerized microtomography and confocal microscopy demonstrated a decrease in bone neoformation, as well as tissue mineralization, porosity and bone volume. Estrogen has a protective effect on osteocytes. Since there is deprivation of this hormone, osteocytes are more prone to apoptosis. Studies suggest that the loss of osteocytes 
promotes the recruitment of osteoclasts. These findings correlate with the finding that living osteocytes secrete a growth factor (TGF- $\beta$ ) that inhibits osteoclastogenesis and bone resorption (Henriksen et al., 2009).

Treatment with OPG-Fc promoted better histological characteristics, presenting more mature bone tissue when compared to the OVX group. The OPG expression remained moderate, however, RANKL expressed itself in a discrete way, a behavior resulting from the anti-RANKL action of the drug administered in this experimental group. Consequently, the immunomark for TRAP manifested itself mildly, resulting from RANKL inhibition, resulting in less active osteoclasts and bone resorption. Although the histological results were favorable to the group treated with OPG-Fc, the parameters of computerized microtomography were impaired by the action of the drug. Porosity, bone volume, amount and thickness of trabeculae were inferior to SHAM and OVX groups. Evidencing the antiabsorptive effect of OPG-Fc, we observed important preservation of the old bone, represented by the precipitation of fluorochrome calcein. This result is reflected in the mineral apposition rate values, which are higher than the OVX group values. However, when we observe the precipitation of alizarin fluorochrome, representing the most recent bone, we notice precarious bone formation. These findings suggest that inhibition of osteoclastogenesis is not beneficial when we need the process of bone remodeling to repair the bone.

Bone remodeling is vital for the bone, since the damage caused to the bone tissue by trauma and age is repaired by the action of this process (Roodman, 1999). Osteoblasts and osteoclasts are rigorously coordinated by growth factors and hormones so that the remodeling cycle is balanced (Seeman \& Delmas., 2006). Remodeling begins with the process of bone resorption, mediated by the death of osteocytes at the site where the mechanical stress was exercised. This leads to osteoclastogenesis and bone resorption of the damaged bone matrix. After resorption, the osteoclasts suffer apoptosis and osteoblast precursors are recruited to begin bone formation by the osteoblasts of the resorbed area. Osteoblasts are also mediator cells of osteoclastogenesis. Through the secretion of RANKL and M-CSF, osteoblasts stimulate the activation of osteoclasts so that they perform the reabsorption of the compromised bone. By another mechanism, osteoblasts secrete osteoprotegerin (OPG) which has the important role of neutralizing RANKL, inhibiting signaling for osteoclastic formation and bone resorption (Henriksen et al., 2009). Thus, it is essential that the processes of bone resorption and formation occur in a coordinated manner for the restoration and maintenance of healthy bone tissue. Any stimulus at any stage of bone remodeling can impair the balance between resorption and formation and thus lead to metabolic changes such as osteoporosis and osteopetrosis (Karsdal et al., 2007).

Since bone remodeling requires coupling between resorption activities and bone formation, we can state that inhibiting the resorption pathway can hinder the complex process of bone remodeling that guarantees the integrity of the bone. This explains the inferior results of the OVX/OPG-Fc group compared to the OVX group. In a study conducted by Martin in 2004 (Martin, 2004) it was demonstrated that for the anabolic action of parathyroid hormone to occur, bone resorption may be necessary, suggesting that bone neoformation depends on signals emitted by osteoclasts. Furthermore, there is evidence that there is a bidirectional signaling between osteoblasts and osteoclasts, through the expression of EphrinB2 by osteoclasts that induces bone formation via attachment to EphB4 produced by osteoblasts, while the expression of EphB4 negatively modulates osteoclastogenesis through attachment to EphrinB2. Thus, osteoclasts can possibly stimulate the differentiation of osteoblasts in the bone formation phase (Zhao et al., 2006).

Confirming these findings, a human study in which denosumab was used as a treatment for post menopausal osteoporosis demonstrated that antibody treatment against RANKL radically reduced bone resorption, considerably increasing bone mineral density. However, biochemical markers of bone formation were reduced as well as bone turnover (McClung et al., 2006). These data are still supported by a study in knock-in mice expressing human RANKL and were treated with denosumab antiabsorbent, which shows significant reduction in histomorphometric levels of bone formation, as well as 
significant reductions in mineralization of the trabecular surface, mineral apposition rate and bone formation rate (Kostenuik et al., 2009).

Thus, the inhibition of RANKL interrupts the regulation of osteoclastogenesis, however, due to the coupling process, it is expected that, in turn, the reduction in the number and activity of osteoclasts will affect the cytokines derived from osteoclasts and the release of matrix-derived growth factors during resorption, thus reducing bone formation. This phenomenon probably occurs with most anti-resorptive drugs, such as denosumab and biphosphonates (Baron et al., 2011).

Another important aspect to be addressed is the growing number of cases of osteonecrosis of the jaws associated with the use of denosumab. There is evidence that the absence of differentiation and function of osteoclasts favors the occurrence of osteonecrosis of the jaws (Aghaloo et al., 2010).

In light of these findings, the clinical and dental conduct in patients who make use of denosumab should be cautious, since invasive procedures in bone tissue can generate complications that lead to treatment failure and compromise the individual's health.

In this study, treatment with OPG-Fc in rats with estrogen deficiency exerted a powerful anti-absorbent action on bone tissue, however, this action impaired the functioning of the signaling pathway responsible for modulating the bone remodeling cycle, leading to deterioration of the alveolar bone microarchitecture.

\section{Conclusion}

In view of the results, it is possible to conclude that the OPG-Fc plays an important anti-absorptive action on the bone tissue under repair, preventing loss of pre-existing bone tissue caused by excessive osteoclastogenesis, characteristic of estrogen deficiency. However, such mechanism of action is not enough to promote bone neoformation, causing delay in the alveolar repair process. Further studies will be developed using other bone repair evaluation models using this medication.

\section{Acknowledgments}

The São Paulo Research Foudation - FAPESP grant 2017/23400-5 and 2015/14688-0, financially supported this work. We are grateful to the multi-user laboratory of the Faculty of Dentistry of Araçatuba / UNESP for the use of the computerized microtomograph ((process 01.12.0530.00 FINEP / Proinfra 01/2011).

\section{References}

Adami, S., Libanati, C., Boonen, S., Cummings, S. R., Ho, P. R., Wang, A., Siris, E., Lane, J., FREEDOM Fracture-Healing Writing Group, Adachi, J. D., Bhandari, M., de Gregorio, L., Gilchrist, N., Lyritis, G., Möller, G., Palacios, S., Pavelka, K., Heinrich, R., Roux, C., \& Uebelhart, D. (2012). Denosumab treatment in postmenopausal women with osteoporosis does not interfere with fracture-healing: results from the FREEDOM trial. The Journal of bone and joint surgery. American volume, 94(23), 2113-2119. https://doi.org/10.2106/JBJS.K.00774

Aghaloo, T. L., Felsenfeld, A. L., \& Tetradis, S. (2010). Osteonecrosis of the jaw in a patient on Denosumab. Journal of oral and maxillofacial surgery official journal of the American Association of Oral and Maxillofacial Surgeons, 68(5), 959-963. https://doi.org/10.1016/j.joms.2009.10.010

Baron, R., Ferrari, S., \& Russell, R. G. (2011). Denosumab and bisphosphonates: different mechanisms of action and effects. Bone, 48(4), 677-692. https://doi.org/10.1016/j.bone.2010.11.020

Bouxsein, M. L., Boyd, S. K., Christiansen, B. A., Guldberg, R. E., Jepsen, K. J., \& Müller, R. (2010). Guidelines for assessment of bone microstructure in rodents using micro-computed tomography. Journal of bone and mineral research: the official journal of the American Society for Bone and Mineral Research, 25(7), 1468-1486. https://doi.org/10.1002/jbmr.141

de Oliveira Puttini, I., Gomes-Ferreira, P., de Oliveira, D., Hassumi, J. S., Gonçalves, P. Z., \& Okamoto, R. (2019). Teriparatide improves alveolar bone modelling after tooth extraction in orchiectomized rats. Archives of oral biology, 102, 147-154. https://doi.org/10.1016/j.archoralbio.2019.04.007

Eastell R. (1998). Treatment of postmenopausal osteoporosis. The New England journal of medicine, 338(11), 736-746. https://doi.org/10.1056/NEJM199803123381107 
Evans, H. M., \& Long, J. A. (1922). Characteristic Effects upon Growth, Oestrus and Ovulation Induced by the Intraperitoneal Administration of Fresh Anterior Hypophyseal Substance. Proceedings of the National Academy of Sciences of the United States of America, 8(3), 38-39. https://doi.org/10.1073/pnas.8.3.38

Gallagher J. C. (2008). Advances in bone biology and new treatments for bone loss. Maturitas, 60(1), 65-69. https://doi.org/10.1016/j.maturitas.2008.04.005

Gerstenfeld, L. C., Sacks, D. J., Pelis, M., Mason, Z. D., Graves, D. T., Barrero, M., Ominsky, M. S., Kostenuik, P. J., Morgan, E. F., \& Einhorn, T. A. (2009). Comparison of effects of the bisphosphonate alendronate versus the RANKL inhibitor denosumab on murine fracture healing. Journal of bone and mineral research : the official journal of the American Society for Bone and Mineral Research, 24(2), 196-208. https://doi.org/10.1359/jbmr.081113

Henriksen, K., Neutzsky-Wulff, A. V., Bonewald, L. F., \& Karsdal, M. A. (2009). Local communication on and within bone controls bone remodeling. Bone, 44(6), 1026-1033. https://doi.org/10.1016/j.bone.2009.03.671

Ikeda, T., Utsuyama, M., \& Hirokawa, K. (2001). Expression profiles of receptor activator of nuclear factor kappaB ligand, receptor activator of nuclear factor $\mathrm{kappaB}$, and osteoprotegerin messenger RNA in aged and ovariectomized rat bones. Journal of bone and mineral research: the official journal of the American Society for Bone and Mineral Research, 16(8), 1416-1425. https://doi.org/10.1359/jbmr.2001.16.8.1416

Karsdal, M. A., Martin, T. J., Bollerslev, J., Christiansen, C., \& Henriksen, K. (2007). Are nonresorbing osteoclasts sources of bone anabolic activity? Journal of bone and mineral research: the official journal of the American Society for Bone and Mineral Research, 22(4), 487-494. https://doi.org/10.1359/jbmr.070109

Kostenuik, P. J., Capparelli, C., Morony, S., Adamu, S., Shimamoto, G., Shen, V., Lacey, D. L., \& Dunstan, C. R. (2001). OPG and PTH-(1-34) have additive effects on bone density and mechanical strength in osteopenic-ovariectomized rats. Endocrinology, 142(10), 4295-4304. https://doi.org/10.1210/endo.142.10.8437

Kostenuik, P. J., Nguyen, H. Q., McCabe, J., Warmington, K. S., Kurahara, C., Sun, N., Chen, C., Li, L., Cattley, R. C., Van, G., Scully, S., Elliott, R., Grisanti, M., Morony, S., Tan, H. L., Asuncion, F., Li, X., Ominsky, M. S., Stolina, M., Dwyer, D., \& Sullivan, J. K. (2009). Denosumab, a fully human monoclonal antibody to RANKL, inhibits bone resorption and increases BMD in knock-in mice that express chimeric (murine/human) RANKL. Journal of bone and mineral research: the official journal of the American Society for Bone and Mineral Research, 24(2), 182-195. https://doi.org/10.1359/jbmr.081112

Luvizuto, E. R., Queiroz, T. P., Dias, S. M., Okamoto, T., Dornelles, R. C., Garcia, I. R., Jr, \& Okamoto, R. (2010). Histomorphometric analysis and immunolocalization of RANKL and OPG during the alveolar healing process in female ovariectomized rats treated with oestrogen or raloxifene. Archives of oral biology, 55(1), 52-59. https://doi.org/10.1016/j.archoralbio.2009.11.001

Manrique, N., Pereira, C. C., Luvizuto, E. R., Sánchez, M., Okamoto, T., Okamoto, R., Sumida, D. H., \& Antoniali, C. (2015). Hypertension modifies OPG, RANK, and RANKL expression during the dental socket bone healing process in spontaneously hypertensive rats. Clinical oral investigations, 19(6), 13191327. https://doi.org/10.1007/s00784-014-1369-0

Martin T. J. (2004). Does bone resorption inhibition affect the anabolic response to parathyroid hormone? Trends in endocrinology and metabolism: TEM, 15(2), 49-50. https://doi.org/10.1016/j.tem.2004.01.002

McClung, M. R., Lewiecki, E. M., Cohen, S. B., Bolognese, M. A., Woodson, G. C., Moffett, A. H., Peacock, M., Miller, P. D., Lederman, S. N., Chesnut, C. H., Lain, D., Kivitz, A. J., Holloway, D. L., Zhang, C., Peterson, M. C., Bekker, P. J., \& AMG 162 Bone Loss Study Group (2006). Denosumab in postmenopausal women with low bone mineral density. The New England journal of medicine, 354(8), 821-831. https://doi.org/10.1056/NEJMoa044459

Miyazaki, T., Matsunaga, T., Miyazaki, S., Hokari, S., \& Komoda, T. (2004). Changes in receptor activator of nuclear factor-kappaB, and its ligand, osteoprotegerin, bone-type alkaline phosphatase, and tartrate-resistant acid phosphatase in ovariectomized rats. Journal of cellular biochemistry, 93(3), 503512. https://doi.org/10.1002/jcb.20201

Nakamichi, Y., Udagawa, N., Kobayashi, Y., Nakamura, M., Yamamoto, Y., Yamashita, T., Mizoguchi, T., Sato, M., Mogi, M., Penninger, J. M., \& Takahashi, N. (2007). Osteoprotegerin reduces the serum level of receptor activator of NF-kappaB ligand derived from osteoblasts. Journal of immunology (Baltimore, Md: 1950), 178(1), 192-200. https://doi.org/10.4049/jimmunol.178.1.192

Okamoto, T., \& de Russo, M. C. (1973). Wound healing following tooth extraction. Histochemical study in rats. Revista da Faculdade de Odontologia de Aracatuba, 2(2), 153-169.

Ominsky, M. S., Li, X., Asuncion, F. J., Barrero, M., Warmington, K. S., Dwyer, D., Stolina, M., Geng, Z., Grisanti, M., Tan, H. L., Corbin, T., McCabe, J., Simonet, W. S., Ke, H. Z., \& Kostenuik, P. J. (2008). RANKL inhibition with osteoprotegerin increases bone strength by improving cortical and trabecular bone architecture in ovariectomized rats. Journal of bone and mineral research: the official journal of the American Society for Bone and Mineral Research, 23(5), 672-682. https://doi.org/10.1359/jbmr.080109

Pedrosa, W. F., Jr, Okamoto, R., Faria, P. E., Arnez, M. F., Xavier, S. P., \& Salata, L. A. (2009). Immunohistochemical, tomographic and histological study on onlay bone graft remodeling. Part II: calvarial bone. Clinical oral implants research, 20(11), 1254-1264. https://doi.org/10.1111/j.1600-0501.2009.01747.x

Ramalho-Ferreira, G., Faverani, L. P., Momesso, G., Luvizuto, E. R., de Oliveira Puttini, I., \& Okamoto, R. (2017). Effect of antiresorptive drugs in the alveolar bone healing. A histometric and immunohistochemical study in ovariectomized rats. Clinical oral investigations, 21(5), 1485-1494. https://doi.org/10.1007/s00784-016-1909-x

Roodman G. D. (1999). Cell biology of the osteoclast. Experimental hematology, 27(8), 1229-1241. https://doi.org/10.1016/s0301-472x(99)00061-2

Samadfam, R., Xia, Q., \& Goltzman, D. (2007). Co-treatment of PTH with osteoprotegerin or alendronate increases its anabolic effect on the skeleton of oophorectomized mice. Journal of bone and mineral research: the official journal of the American Society for Bone and Mineral Research, 22(1), 55-63. https://doi.org/10.1359/jbmr.060915 
Research, Society and Development, v. 10, n. 1, e43710111975, 2021

(CC BY 4.0) | ISSN 2525-3409 | DOI: http://dx.doi.org/10.33448/rsd-v10i1.11975

Seeman, E., \& Delmas, P. D. (2006). Bone quality--the material and structural basis of bone strength and fragility. The New England journal of medicine, 354(21), 2250-2261. https://doi.org/10.1056/NEJMra053077

Simonet, W. S., Lacey, D. L., Dunstan, C. R., Kelley, M., Chang, M. S., Lüthy, R., Nguyen, H. Q., Wooden, S., Bennett, L., Boone, T., Shimamoto, G., DeRose, M., Elliott, R., Colombero, A., Tan, H. L., Trail, G., Sullivan, J., Davy, E., Bucay, N., Renshaw-Gegg, L., \& Boyle, W. J. (1997). Osteoprotegerin: a novel secreted protein involved in the regulation of bone density. Cell, 89(2), 309-319. https://doi.org/10.1016/s0092-8674(00)80209-3

Teófilo, J. M., Brentegani, L. G., \& Lamano-Carvalho, T. L. (2004). Bone healing in osteoporotic female rats following intra-alveolar grafting of bioactive glass. Archives of oral biology, 49(9), 755-762. https://doi.org/10.1016/j.archoralbio.2004.02.013

Yoneda, T., Ishimaru, N., Arakaki, R., Kobayashi, M., Izawa, T., Moriyama, K., \& Hayashi, Y. (2004). Estrogen deficiency accelerates murine autoimmune arthritis associated with receptor activator of nuclear factor-kappa B ligand-mediated osteoclastogenesis. Endocrinology, 145(5), $2384-2391$. https://doi.org/10.1210/en.2003-1536

Zhao, C., Irie, N., Takada, Y., Shimoda, K., Miyamoto, T., Nishiwaki, T., Suda, T., \& Matsuo, K. (2006). Bidirectional ephrinB2-EphB4 signaling controls bone homeostasis. Cell metabolism, 4(2), 111-121. https://doi.org/10.1016/j.cmet.2006.05.012 